\title{
4H Project Guide: Swine Nutrition ${ }^{1}$
}

\section{R.O. Myer and J. H. Brendemuhl ${ }^{2}$}

A dependable and economical source of feed is the basis of a profitable hog operation. In fact, 40 to $60 \%$ of the total cost of producing hogs is feed. Thus, 4-Hers who raise hogs need to be keenly aware of the types of feed available.

\section{Ingredients Needed}

Swine rations, whether bought or mixed on the farm, usually contain a ground cereal grain, a protein source (usually soybean meal), salt, a calcium source, a phosphorus source, a vitamin-trace mineral premix, and an antibiotic premix. Other ingredients commonly added are milk by-products such as dried whey, ground alfalfa hay, or dehydrated alfalfa meal; meat by-products such as meat and bone scraps or tankage and cereal grain by-products such as wheat bran, wheat mids, or rice bran.

\section{Choice of Cereal Grains}

About $50-85 \%$ of the ingredients in swine rations are cereal grains. They are the main way of providing energy (or calories) in swine rations.

Corn is the cereal grain (energy source) preferred by most pork producers and is best in feeding value. However, other cereal grains, at times, may be a better buy.

Grain Sorghum, often called milo, is sometimes fed to hogs. Good quality grain sorghum has about $95 \%$ of the feeding value of corn. Grain sorghum has a protein and animo acid (building blocks of protein) composition similar to corn and can be interchanged on a pound-for-pound basis with corn.

Barley is occasionally fed to hogs. It has an energy value of about $90 \%$ that of corn. Its lower feeding value is caused by its high fiber content. You get best results by feeding a mixture of barley with either corn or grain sorghum. Barley grown in the south is usually of low quality, and its value is much lower than $90 \%$ of the value of corn. You should not use such barley in rations for very young pigs.

Wheat is an excellent swine feed, with an energy value of about 98 to $100 \%$ of corn. Sometimes it is priced low enough to be considered for pig rations. Some pork producers prefer to feed a mixture of wheat and corn or grain sorghum because they feel performance is better with a combination of grain sources. However, wheat can be the only source of grain.

1. This document is $4 \mathrm{H} 225$, one of a series of the Animal Science Department, Florida Cooperative Extension Service, Institute of Food and Agricultural Sciences, University of Florida. Original publication date July 1, 1988 as 4HSR-17. Reviewed May 8, 2003. Visit the EDIS Web Site at http://edis.ifas.ufl.edu.

2. R.O. Myer, Professor of Animal Sciences, North Florida Research and Education Center, Marianna, Florida and J.H. Brendemuhl, Professor of Animal Sciences, Department of Animal Sciences; Florida Cooperative Extension Service, Institute of Food and Agricultural Sciences, University of Florida, Gainesville, Florida 32611.

The Institute of Food and Agricultural Sciences (IFAS) is an Equal Employment Opportunity - Affirmative Action Employer authorized to provide research, educational information and other services only to individuals and institutions that function without regard to race, creed, color, religion, age, disability, sex, sexual orientation, marital status, national origin, political opinions or affiliations. For information on obtaining other extension publications, contact your county Cooperative Extension Service office. Florida Cooperative Extension Service / Institute of Food and Agricultural Sciences / University of Florida / Larry R. Arrington, Interim Dean 


\section{Swine Rations}

Four to five (or even more) rations are usually required in complete farrow-to-finish hog operations. The basic ones are bred sow (gestation), nursing sow (lactation), starter (young pigs 20 to 40 pounds), growing rations (40 to 120 pounds), and finishing rations (120 pounds to market). Some producers may use the same ration for bred sows and nursing sows. Boars are usually fed the bred sow ration. Table 1 gives example swine rations that may be mixed on the farm if a pork producer has a feed mill.

\section{Methods of Getting Swine Rations}

Here are six ways of getting swine rations:

1. Buy complete commercial rations by the bag. This is usually the most expensive method. The added cost of bagging and handling compared to bulk feed and often the sale of small quantities cause higher prices. However, if you are feeding just a few pigs, this may be your only option.

2. You may buy complete commercial rations in bulk (not bagged) and delivered directly to bulk tanks or large self-feeders on the farm. The cost of this service includes mark-up on ingredients and charges of grinding, mixing, and delivery.

\section{Producers can often get a custom mix of a} complete ration made at a feed mill. Pork producers may deliver all the ingredients to the mill, have grain stored at the mill, and buy the additional ingredients from the mill or buy all ingredients from the mill. The cost may include handling and storage charges, mark-up on ingredients, and charges for grinding, mixing, and delivery.

\section{You may buy complete supplements for} mixing with ground grain on the farm. Two or three different supplements are usually required for farrow-to-finish systems (i.e. for sow feeds, starter feeds, and growing-finishing feeds). Supplements required in small quantities are bought in bags. Larger volumes usually justify bulk handling.
5. You can buy base mixes (complete premixes) in bags and mix with soybean meal and ground grain on the farm. This usually involves two or three different base mixes for farrow-to-finish systems. Base mixes are usually sold to be added at the rate of 50 to 100 pounds to a ton of complete feed.

\section{You can prepare base mixes (complete} premixes) on the farm. A mixer of the appropriate size and design is essential to insure adequate mixing. Each base mix is then mixed with soybean meal and ground grain to produce the ration. Required bagged ingredients include salt, calcium source, phosphorus source, and vitamin-trace mineral and antibiotic premixes. This method is used by many producers with 100 or more sows because it offers greater flexibility in ration formulation and lower ingredient costs.

\section{Further information:}

1. Local county extension service

2. Pork Industry Handbook (available through

Purdue University Extension Service):

www.ces.purdue.edu/extmedia/ansci.htm

a. Swine rations - PIH-23

b. On farm feed processing - PIH-4

3. Websites :

a. edis.ifas.ufl.edu/TOPIC_4H_Animal_Science

b. edis.ifas.ufl.edu/TOPIC_Swine

c. edis.ifas.ufl.edu/TOPIC_4H_Swine

d. tcebookstore.org/pubinfo.cfm?pubid=1541

e. animalscience.tamu.edu/ansc/index.htm (click on youth projects). 
Table 1. Example rations fed to pigs.

\begin{tabular}{|c|c|c|c|c|c|}
\hline Ingredients & $\begin{array}{l}20 \text { to } \\
40 \text { Lb. }\end{array}$ & $\begin{array}{r}40 \text { to } \\
125 \text { Lb. }\end{array}$ & $\begin{array}{l}125 \mathrm{Lb} \text {. } \\
\text { to Market }\end{array}$ & $\begin{array}{l}\text { Gestating } \\
\text { Sows }\end{array}$ & $\begin{array}{c}\text { Nursing } \\
\text { Sows }\end{array}$ \\
\hline Corn, yellow & 1040 & 1545 & 1645 & 1675 & 1535 \\
\hline Oat groats & 200 & -- & -- & -- & -- \\
\hline Soybean meal, $48 \%$ & 500 & 400 & 300 & 250 & 400 \\
\hline Dried whey & 200 & -- & -- & -- & -- \\
\hline Calcium carbonate & 15 & 15 & 17 & 20 & 15 \\
\hline Dicalcium phosphate & 30 & 27 & 25 & 40 & 30 \\
\hline Salt & 10 & 10 & 10 & 10 & 10 \\
\hline Vitamin-trace mineral mix & 5 & 3 & 3 & 5 & 5 \\
\hline Antibiotics $^{a}$ & + & + & + & + & + \\
\hline Total & 2000 & 2000 & 2000 & 2000 & 2000 \\
\hline Protein, \% & 18.5 & 16.0 & 14.1 & 13.0 & 16.0 \\
\hline Lysine, \% & 0.95 & 0.80 & 0.66 & 0.60 & 0.80 \\
\hline Calcium, \% & 0.78 & 0.64 & 0.65 & 0.90 & 0.75 \\
\hline Phosphorus, \% & 0.66 & 0.56 & 0.54 & 0.70 & 0.60 \\
\hline
\end{tabular}

